\title{
A BRIEF REPLY TO PROFESSOR LEACH
}

\section{Phin Mechem $\dagger$}

When I read Mr. Leach's article, my reaction, perhaps oddly, was one of mixed relief and disappointment. Relief-because I had feared that with his unquestioned ability and mastery of the subject he might show up my ignorance and the erroneous nature of my reasoning to an embarrassing extent. Disappointment-because my humble offering was the result of some ten years' painful thinking on the problem, and I had looked forward to having a careful and impartial appraisal of my thoughts by a highly competent judge. I think it not rude to say that Mr. Leach has not made a fair-minded appraisal of it, because he has made virtually no appraisal at all.

I should note a few exceptions to this. In one instance, I am happy to yield. I ventured to state that on the basis of my reading of the cases and of the figures given in Mr. Waterbury's excellent article, ${ }^{1}$ I doubted that the Rule was causing an undue amount of hardship: more, that is, than any other rule however well conceived and drafted must necessarily cause in a world of ignorant testators and less than skilled attorneys-for instance, the rule that wills must be in writing and signed by the testator. Mr. Leach says that in his practice and in his contact with many lawyers in many states, he finds that the Rule is a constant source of trouble to an extent not suggested by the reported cases. I am not engaged in the estate practice, and I would not attempt to deny his statement. I can only say that in my experience the reported cases normally afford at least a rough index to the activity in a given area, and they do not suggest to me that the Rule is causing a "slaughter of the Innocents." Incidentally, Mr. Leach appears to resent my perhaps crude suggestion that his writings in this area have been "intemperate," and yet he himself remarks (p. 1152) that he "hammed up" his articles to make them better propaganda.

As to his other few references to points I attempted to make, I have to say that they are either evasive or abusive. Item: I suggested that policy would dictate an early determination of the validity of remainders so that those interested would know where they stand. Thus, to use the illustration suggested below to test the working of the statute, $T$ leaves his property to his wife for life and then to the children

† Professor of Law, University of Pennsylvania Law School. LL.B. 1922, University of Colorado; J.S.D. 1926, University of Chicago.

1 Waterbury, Some Further Thoughts on Perpetuities Reform, 42 MINN. L. Rev. 41 (1957). 
of his brother, $B$, who reach twenty-five. $T$ 's father, $F$, is his heir ; the wife elects to take under the will; and $B$ is alive. It would seem to me self-evident that it is to the interest of everyone that $F$ should be able to obtain an immediate judicial determination that he is the owner of the reversion. And whether or not this is self-evident, I cannot conceive how the nature of the proposition I am asserting could be misunderstood. Mr. Leach, however, elects to misunderstand. His response (p. 1138): "And whose policy? Certainly not that of the Pennsylvania courts-or the Massachusetts courts either-both of which refuse to pass upon the validity of a gift under the Rule Against Perpetuities until prior estates have ended." That is not news to me, nor is it remotely responsive to the suggestion I made.

Item: I suggested (which is very obvious and has often been suggested before) that under the Pennsylvania statute it is difficult to know what life (or lives) can be used as the life (or lives) in being. I supposed the following limitation-to testator's widow for life and then to his brother's children who reach twenty-five-and speculated whether in addition to the brother's life, that of the widow, the lawyer named by $T$, or the gardener to whom he left instructions might not be used. Nothing, I believed (and still do), in the statute prevents it or, indeed, throws any light on the question. Leach thinks (rather oddly, it appears to me, since the interpretation under the common-law Rule is clearly otherwise) that the wife's life will do inasmuch as there can be no distribution until her death and the Pennsylvania courts will not determine the matter until then. What these facts have to do with it is not clear; the question when the brother's children reach twenty-five has nothing whatsoever to do with the widow's life. Leach neatly and politely disposes of my suggestion that the lawyer's or gardener's life might do: it is so "patently frivolous as to violate the standards of dignity" which the court is entitled to expect. (p.1144). Worse, the suggestion is "nonsense," (id.) and the illustration itself is a "museum piece." (p. 1143). In passing, he makes a reflection on my supposed teaching methods (p. 1143) and reflects comfortably (n.51) that I must be slandering my students in attributing to them ideas inconsistent with the gospel according to Leach. Finally, I am apparently not familiar with the work of my friend and colleague, Philip Brégy, who has clarified the matter by saying that lives may be used that are "reasonably related to the gift" - whatever that may mean. For example, one need only consider Johnston's Estate: ${ }^{2}$ a gift in substance to $T^{\prime}$ 's issue living seventy-five years hence, obviously bad at common law, as was held by 
the court. (Incidentally, although it does not appear just what precipitated the decision, the court did not make the heirs wait seventy-five years to find out what their rights were.) Mr. Brégy says that the period does not expire "until twenty-one years after the death of [all?] descendants living at testator's death." ${ }^{3}$ With all respect, it is hard to find any support for this in the statute. (That is, unless he is favorably disposed to the idea I hinted at above, that virtually any life will dowhich I am sure he is not.)

Item: Mr. Leach, after adverting to the fact that the Report of the English Law Reform Committee adopts wait-and-see, remarks (p. 1152) : "it may be inferred that the anti-reformists [sic] don't like this Report but don't know quite what to do about it." On the contrary, I know quite well what I would do about it: thank the learned gentlemen, and respectfully disagree. Perhaps this is what Parliament has done; at least Mr. Leach notes that the Report has not yet been incorporated into legislation. And I cannot forbear adding that when I was originally delivering my remarks at a bar association meeting in Pittsburgh, a learned member of the bar assured me that I must be wrong because the statute had been passed unanimously by the Pennsylvania legislature.

Beyond this, I submit, Mr. Leach has not made any effort to notice, let alone answer, my basic argument. This I think odd, because he says that his article "is basically an answer to Mechem." (p. 1143). Must I think my arguments too contemptible to require comment?

For the benefit of those interested enough to read this far but who do not have the time or opportunity to read the full enunciation of my argument, I shall summarize it briefly.

First: The common-law Rule, as initiated by Lord Nottingham and as developed and crystallized by courts during the centuries since, was not conceived of as turning on the time when the contingent interest actually vested, but rather as a rule outlawing absolutely and $a b$ initio interests which by their nature-that is, by the terms of the limitation-were likely to vest at an undesirably remote time. Thus immediate determination of the validity of future interests is possible, an obvious boon to those concerned. The idea of "wait-and-see" was wholly foreign to the common-law Rule; this, of course, does not show that wait-and-see is bad, but it is significant in view of the eagerness with which its exponents insist it is only a modification of the commonlaw Rule when in fact it is an almost wholly different scheme having only an external resemblance to the common-law concept. For a rule (that is, the common-law Rule) so conceived, measurement by lives in

3 Brégy, Intestate, Wills and Estates Acts of 1947, at 5271 (1949). 
being and twenty-one years was both natural and reasonable, because it permitted what an ordinary testator would most commonly wish to do: leave a life estate to the spouse and a remainder to children on attaining majority. Granting the purpose and theory of the Rule, it is hard to think of a better measure to use; and, in fact, the common-law Rule has not worked badly and would meet little criticism if certain unnecessary eccentricities in its application were eliminated, as they easily could be. These oddities are primarily the rules in Jee v. Audley ${ }^{4}$ that a woman is conclusively presumed capable of having children no matter what her age, and in Leake v. Robinson ${ }^{5}$ that it must be certain that the interests of all possible members of a class will vest within the period. The further improvement would be to permit courts to cut down, where necessary, provisions postponing vesting until an age greater than twenty-one-the so-called cy pres interpretation permitted under a number of modern statutes.

Second: If, despite improvements in the common-law Rule, dissatisfaction persists and it is insisted that the nature of the Rule be changed so as to make the validity of remainders depend upon the time when they actually vest, the common-law measurement is patently illadapted to the purpose and another one should be substituted. This is so for two reasons. Firstly, the wait-and-see rule will often make the validity of remainders depend upon a purely fortuitous circumstance, usually, how long a parent lives. For instance, under a gift to my wife for life and then to my brother's children who reach twenty-five, the remainder may be bad although it vests in twenty-six years or good although it does not vest for seventy-six, depending on the subsequent history of the brother. Secondly, there is nothing in the wait-and-see doctrine that permits determination, easily made at common law, of what are permissible lives in being. For instance, nothing in the Pennsylvania statute prohibits using the life of anyone alive both at vesting and at $T$ 's death. This, it seems to me, reduces the matter to absurdity. What should be substituted I hate to suggest-perhaps a period in gross such as seventy-five years. And if this seems unreasonable, consider what is apparently now the law under the will set forth above: brother dies with children, nine and fifteen, and one aged three; if that child lives to reach twenty-five, the gift to all is bad.

My reasoning may be sensible, nonsensical, or a little of both. I make no claim for it, save that in an article supposedly devoted to it, it should be fairly considered and fairly evaluated-neither of which, I submit, Mr. Leach has done. 